\title{
Needs Analysis of Literacy Assessment Using Blended Learning for Beginner EFL Learners
}

\author{
Ni Nyoman Padmadewi \\ Universitas Pendidikan Ganesha, Indonesia \\ Luh Putu Artini \\ Universitas Pendidikan Ganesha, Indonesia \\ Ni Made Ratminingsih \\ Universitas Pendidikan Ganesha, Indonesia \\ IGA Lokita Purnamika Utami \\ Universitas Pendidikan Ganesha, Indonesia \\ Ni Putu Era Marsakawati \\ Universitas Pendidikan Ganesha, Indonesia
}

\begin{abstract}
Needs analysis is vital in assessment instrument development because assessment is of paramount importance in teaching and learning. The phenomena of technology developments influence how assessment instruments must be developed to achieve the learning objectives and outcomes. The present study aimed at conducting a needs analysis of literacy assessment using blended learning for beginner EFL learners in Bali, Indonesia. The survey-style research was carried out involving 17 English teachers from 12 public junior high schools. A questionnaire, in-depth interviews, and a focused group discussion were used to collect the data. The data were descriptively analyzed using both quantitative and qualitative methods. The study results revealed that the needs identified in assessment developments consist of the target needs that cover the necessities of assessments, including the assessment of learning, as learning, assessment for learning, wants and lacks. In addition, the learner needs in the form of authentic materials, technology-based materials, skillsbased, and language inputs are all needed in developing instrument assessments. The activities and procedures for conducting assessments in the form of pedagogical and real-life tasks and procedures are required, in addition to the roles of the students as knowledge seekers, problem solvers, collaborators, critical thinkers, and creators. The identified needs were then used as the basis for the framework design. The needs analysis results conducted in this study are expected to inspire teachers in developing research-based assessment instruments in EFL instructions.
\end{abstract}

Index Terms - assessment, blended learning system, needs analysis, EFL instructions

\section{INTRODUCTION}

Needs analysis is essential for both teachers and students (Eslami, 2010). It leads teachers to discover the essential needs of the teaching and learning process. The primary role of needs analysis is to provide crucial data to aid teachers in making appropriate decisions. The needs analysis results help educators examine the students' target needs and learning needs (Akyel \& Ozek, 2010). It is critical in establishing the appropriate learning materials/resources and assessments based on the instructions' needs and objectives, including English literacy instruction.

Literacy is a communication ability that enables a speaker to share information and comprehend what is stated. Literacy is a skill that involves the ability to receive knowledge, interpret it, and communicate it. Literacy is a term that is frequently used to refer to the fundamental ability to read and write (Padmadewi \& Artini, 2018). Humans can utilize a language to obtain information or communicate when they have reading and writing abilities. Recent developments suggest that the meaning of literacy has expanded. Literacy is the ability to utilize diverse abilities, information, and skills in daily life (Damaianti, Abidin, \& Rahma, 2020). Hence, every subject requires and incorporates literacy ability. Literacy is also an essential aspect of English language learning since it enables students to comprehend, create, communicate, and convey information. English literacy has a vital role in education, especially in a learning context, to achieve the learning objectives, and through literacy skills humans can survive in a globalization era (Tryanasari, Aprilia, \& Cahya, 2017).

The 21st century skills were firstly introduced with the $4 \mathrm{C}$ concept: Critical Thinking, Collaboration, Communication, and Creativity. However, the concept was later expanded into 6Cs, in which the new $2 \mathrm{Cs}$; stand for Culture and Citizenship (Miller, 2015), or Character and Citizenship (Fullan \& Duckworth, 2018). This converts the four Cs into six 
Cs: critical thinking, collaboration, creativity, citizenship/culture, and character education/connection. Along with the recent development, students should be prepared to face 21st-century abilities (Nuryana, Suroyo, Nurcahyati, Setiawan, \& Rahman, 2020); and have adequate literacy skills in English language. Students should integrate those skills to achieve the learning goals and be ready for the era of globalization through English literacy (Anugerahwati, 2019).

Teaching English literacy in the 21st-century learning and innovation skills has been found as challenging. Many teachers consider that assessment preparation is time-consuming and exhausting (Aliningsih \& Sofwan, 2015), and requires research-based decision and development (Aziz, Yusoff, \& Yaakob, 2020). Furthermore, the advent of technology in education in the twenty-first century necessitates that teachers modify their teaching and learning activities and their assessments.

The success of English literacy teaching should be conducted by delivering appropriate assessments, by which the learning process and the student's progress can be evaluated. Besides that, the assessments conducted should also allow students to do reflections either by themselves or peers. Assessments also support and improve the students' learning (Nodoushan, 2014). On the literacy side, assessment influences the quality of literacy (Damaianti, Abidin, \& Rahma, 2020).

The teachers' challenges in assessment development are not only originated from the complexity of the skills to be assessed but also how technology can be incorporated into the process of teaching and learning. The alternative model used is advisedly using a blended learning system. Blended learning is defined as the teaching and learning process which is conducted through combining face-to-face and online learning activities (Li, Kay, \& Markovich, 2018). These scholars acknowledge that blended learning supports and encourages the students through enhanced communication by the use of any flexible online platforms. The implementation of blended learning can help the students increase their understanding of foreign languages, such as English (Isti'anah, 2017). Thus, through blended learning, the students can improve and enhance their English literacy skills.

The importance of assessment in foreign language learning is not questionable, and its function in identifying teaching success cannot be denied. This makes assessment is of paramount importance in the process of teaching and learning. The challenges of conducting the assessment is even more nowadays because of the phenomena of having remote and online learning during the COVID-19 pandemic. Many studies investigated teachers' perceptions towards certain kinds of assessment (Eridafithri, 2015; and Zaim, Refnaldi, \& Arsyad, 2020), and the implementation of certain kinds of assessment in English classroom (Aziz \& Yusoff, 2016); Apsari \& Haryudin, 2017); Fahmi, Pratolo, \& Zahruni, 2020; Inayah, Komariah, \& Nasir, 2019; Rahmawanti \& Uman, 2019; Suastra \& Menggo (2020), Sumardi \& Muamaroh, 2020; Yulia, Husin, \& Anuar, 2019). Despite the large number of studies conducted on assessment, a need analysis on what kinds of assessments are needed in order to cover the requirements of having appropriate assessment instruments in the digital era was hardly found. The scarcity of research on the need for analysis of developing instrument assessment motivates the current study. The effects of assessment may be positive or negative depending on several factors, ranging from how the assessment procedure or test is constructed to how it is used (McKay, 2006). It is expected that sound and positive effects of assessment are produced when assessments are assigned to students. For that reason, it is imperative to consider the quality of the assessment instrument used in the process of teaching and learning in order to produce positive and beneficial effects.

The first year of junior high school is the first year of formal English learning instruction in Indonesian schooling, and its success is critical for the next level of teaching and learning. It is, therefore, highly needed to carry out a need analysis study of assessment instruments, especially for beginner EFL learners. For that reason, the objectives of the present study are 1) to analyze the students' target needs and the learner need toward assessments of English literacy in learning English as the first year of junior high school, 2) to analyze the framework of assessment needed using blended learning system.

\section{REVIEW OF RELATED LITERATURE}

Most experts agree that human learning, training, and performance improvement initiatives should begin with a need assessment. A learning or performance gap between the current condition and the desired condition is called a need. In order to identify needs, a need assessment is required. Needs assessment is a process for figuring out how to close a learning or performance gap. It involves determining what the important needs are and how to address them. The process includes comparing the current condition to the desired condition, defining the problem or problems, understanding the behaviors and mechanisms that contribute to the current condition, determining if and how specific behaviors and mechanisms can be changed to produce the desired condition, developing solution strategies, and building support for action (Gupta, Sleezer, \& Russ-Eft, 2007). Learner and target needs are recognized during a needs analysis in the teaching and learning process. The demands of learners are acknowledged as a significant factor that material designers must consider when creating educational materials. Target needs (what the learner must accomplish in the target setting) and learning needs (what the learner must undertake in order to learn) are defined by Hutchinson and Waters (1987). They point out that the target needs are necessities, lacks, and wants. The learner's desire to achieve well in goal-setting can be viewed as a necessity. Lacks also refer to a learner's failure to cope with their goal situation. The learners' expectations after completing the course are linked to their wants. Meanwhile, there are four types of learning demands: input, process, context, and learner role (Nunan, 2004). 
Assessment has the power to change people's lives (Shohamy, 2001). The effects of assessment may be positive or negative depending on a number of factors ranging from the way the assessment procedure or test is constructed to the way it is used. Effective assessment procedures are assessments that have been designed to ensure, as far as possible, valid and fair information on the students' abilities and progress (McKay, 2006).

Assessment takes three approaches: assessment of learning, assessment for learning, and assessment as learning (Priyatni \& Martutik, 2018). Assessment of learning (AOL) is a standard mechanism used by institutions to demonstrate their accountability to students and parents on students' achievement after completing a course. This sort of assessment occurs independently of instructional and learning activities such as midterm and end-of-semester examinations. Teachers do assessments for learning, whereas students conduct assessments for learning. Assessment as learning occurs through self-and peer-assessment. Assessment for learning (AFL) is frequently utilized in the classroom throughout the learning process to foster interaction between teachers and students and increase student motivation to learn. Stiggins (2005) describes assessment for learning as an alternative to the continual use of several assessment methods to document students' mastery of knowledge and skills compared to standards. It emphasizes the importance of utilizing various evaluation methods to ascertain mastery of previously taught concepts, knowledge, and skills. This data can guide instructors, students, and parents to decide their children's educational progress. In other words, assessment for learning is an assessment that occurs during the process of learning and involves either interactive teaching with students or student-to-student interaction.

All types of assessments are demanded in assessing students' literacy. Literacy is a broad term that refers to the capacity to read and write. In a broader sense, literacy is described as the ability to communicate through language, which includes the ability to listen, speak, read, and write, as well as the ability to think critically in real-world situations (Rintaningrum, 2009). Literacy is a real-world activity in which students applies their classroom reading and writing skills to real-world situations such as reading, writing letters to friends, reading food menus, and reading brochures (Purcell-Gates et al., 2012).

Along with the advancement of technology, literacy instruction must incorporate technology, the most prevalent of which is the blended learning method. The phrase blended learning refers to a style of learning that incorporates elements of combining or merging two distinct styles. Cheung and Hew (2011) defined blended learning as a combination of in-person and online instruction. Ramadhan, Chaeruman, and Kustandi (2018) defined blended learning as the process of effectively combining synchronous and asynchronous learning environments in order to accomplish learning objectives. Synchronous learning occurs when activities occur simultaneously and in the same or different locations, whereas asynchronous learning occurs at various times and locations (Littlejohn \& Pegler, 2007). Blended learning incorporates a variety of factors, including but not limited to: methods, media, sources, environment, and learning strategies.

All of the variables as mentioned earlier (literacy, evaluation, and integrated learning) are significant areas of exploration in this study. It is hoped that exploring these variables through needs analysis will provide insight into how assessment instruments are developed for the targeted students.

\section{METHOD}

\section{A. Design}

This study used a survey design that involved 17 English teachers from 12 schools in Bali. The primary purpose of the design is to ascertain community demands for educational services, especially about the needs of assessment instruments required for assessing students' English literacy (Creswell, 2009).

\section{B. Population and Sample}

The population of the research was the English teachers in public junior high schools in Bali. The sample schools first of all, were chosen using a multistage cluster random sampling technique, which resulted in six schools were from the southern part of Bali, while the remaining six were from the northern part of the island. After that a simple random sampling was run to select the schools. Finally, one English teacher was invited to give consent to participate in the study.

\section{Instruments}

Data were gathered through a questionnaire, in-depth interview, focused group discussion, and document analysis. The questionnaire used was based on Hutchinson \& Waters' (1987) requirements analysis tool. It consisted of 22 points of close-ended statements and two open points, which required the respondents to provide answers. The questionnaire was intended to explore the needs for an assessment instrument for teaching English in junior high school. The respondents were 17 English teachers from 12 junior high schools who responded to close questionnaire with two options: 'yes' or 'no'. A definite answer is needed in order to have precise needs. The respondents were asked to pick one of the two possibilities available in the consolidated statements, while the three open points require respondents to suggest needs that they believe should be added. The data from the questionnaire were then used as a guideline in an indepth interview. 


\section{The Data Collecting Procedure}

The study employed four stages to collect data: (1) the questionnaire administration, in which it takes approximately 30 minutes to respond; (2) the in-depth interview followed up the results of the questionnaire analysis and it was intended to seek further clarification; (3) Focused Group Discussions were conducted for one and a half hours using zoom meeting, with the purpose to collect ideas and confirmation about the framework needed ; and 4) the document study was conducted to analyze the syllabus and the textbook to identify the gaps for assessment instruments needed. During the FGD, all teachers were invited to share their knowledge of the target needs and learning needs of their pupils.

\section{E. Data Analysis}

The data were analyzed descriptively using descriptive statistics to determine the respondents' preferred options. At the same time, the findings of the interviews and FGD were analyzed qualitatively. The questionnaire results were provided numerically, whereas the in-depth interview and FGD data were presented qualitatively, as they were based on respondents' responses.

\section{FINDINGS AND DisCUSSION}

With reference to the objectives of the present study previously mentioned, the findings of the study were categorized into two categories as the first one is the students' target needs toward assessments of English literacy in learning English as the first year of junior high school, and the second one is the framework of assessment needed suing blended learning system. The findings were analyzed using Hutchinson and Waters (1987) based on the questionnaire result and the in-depth interview results. The summary of the findings can be summarized in the form of graphs as follows.

\section{A. Target Needs}

Analyzing target needs can be further described into several parts, such as the necessities of the target need on assessment instrument, lacks, kinds of wants. The summary of the findings can be described in the following graphs.

\section{The Necessities of Target Needs on an Assessment Instrument}

Necessities can be described as the aspects of assessments needed by the students in order to be able to achieve the objectives effectively as targeted.

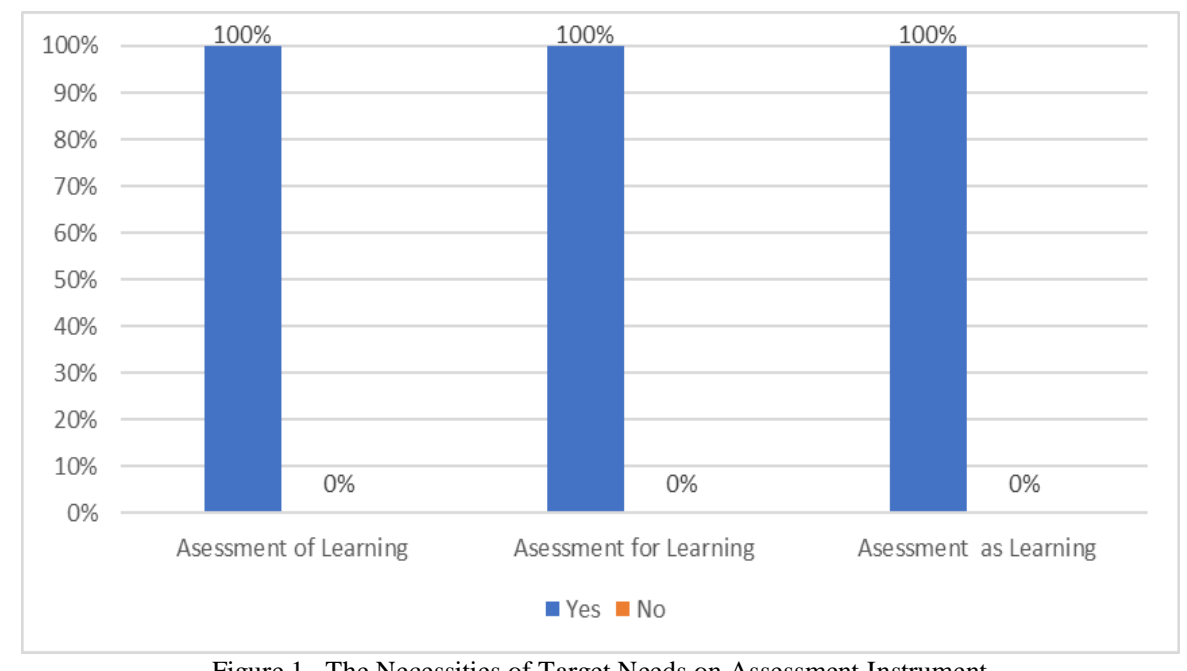

Figure 1. The Necessities of Target Needs on Assessment Instrument

Based on the results of the questionnaire, deep interviews were then conducted. The questionnaire results reveal that there are three types of assessment that need to be developed: assessment of learning, assessment for learning, and assessment of learning. All respondents agreed that all three types of assessments are highly required.

\section{Lacks}

Lacks can be described as what students have not mastered. This is a gap between what has been and what has not been mastered. The information about this can be summarized in Fig. 2. 


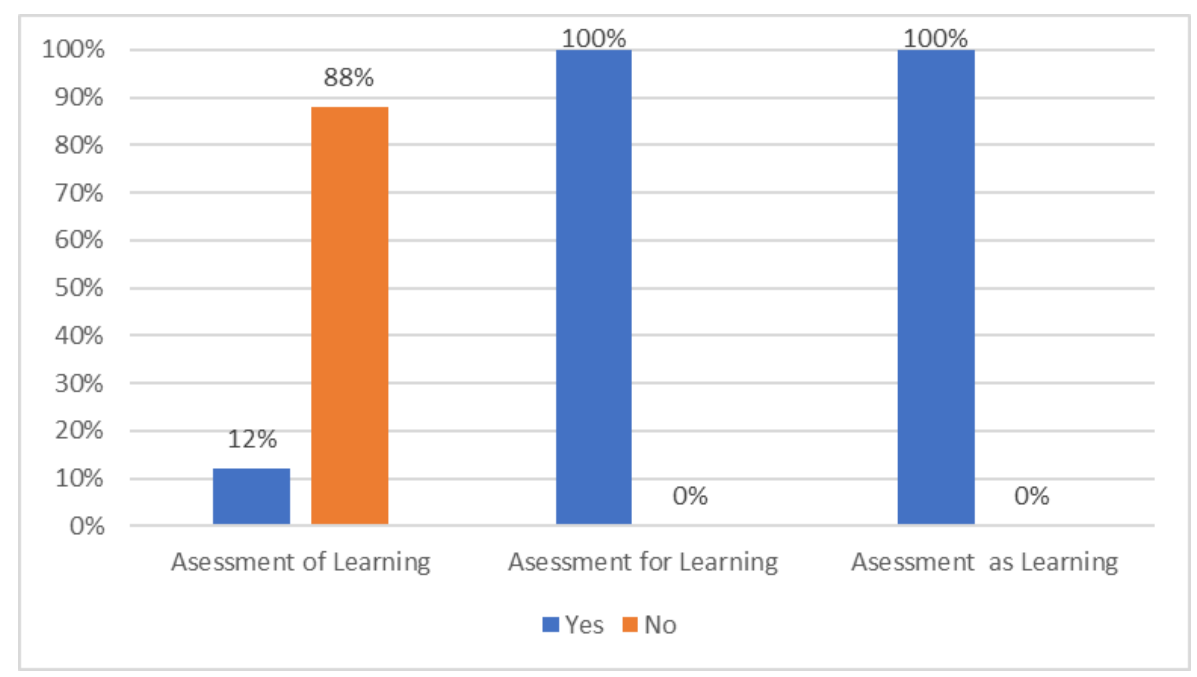

Figure 2. Lack of the Target Needs

Fig. 2 indicates the results of the questionnaire regarding lack. Not all respondents agree that the assessments of learning need to be produced; in fact, $88 \%$ chose the "No" option. Following additional deep interviews with the teachers, as validated by the experts/lecturers on TEFL and assessments, it was revealed that the teachers had already frequently employed the assessment of learning in the form of recognition tests. In other words, they chose "no" for the recognition type of assessment, while the assessments of learning that explore students' critical answers are considered highly needed. Additional interviews revealed that a variety of assessments of learning that place a premium on authentic assessments of language use are still desperately needed. The other two types of assessments, those that serve as assessments for learning (on how much feedback is required for students' progress) and those that serve as assessments for learning (on how well students can write reflections), are also regarded as critical.

\section{Wants}

Wants are related to the expectation from the learners after they are completing the English literacy courses. For that reason, the assessment must be able to deal with the assessments which are intended to fulfill the expectation of the students to have the ability to use English in real -life.

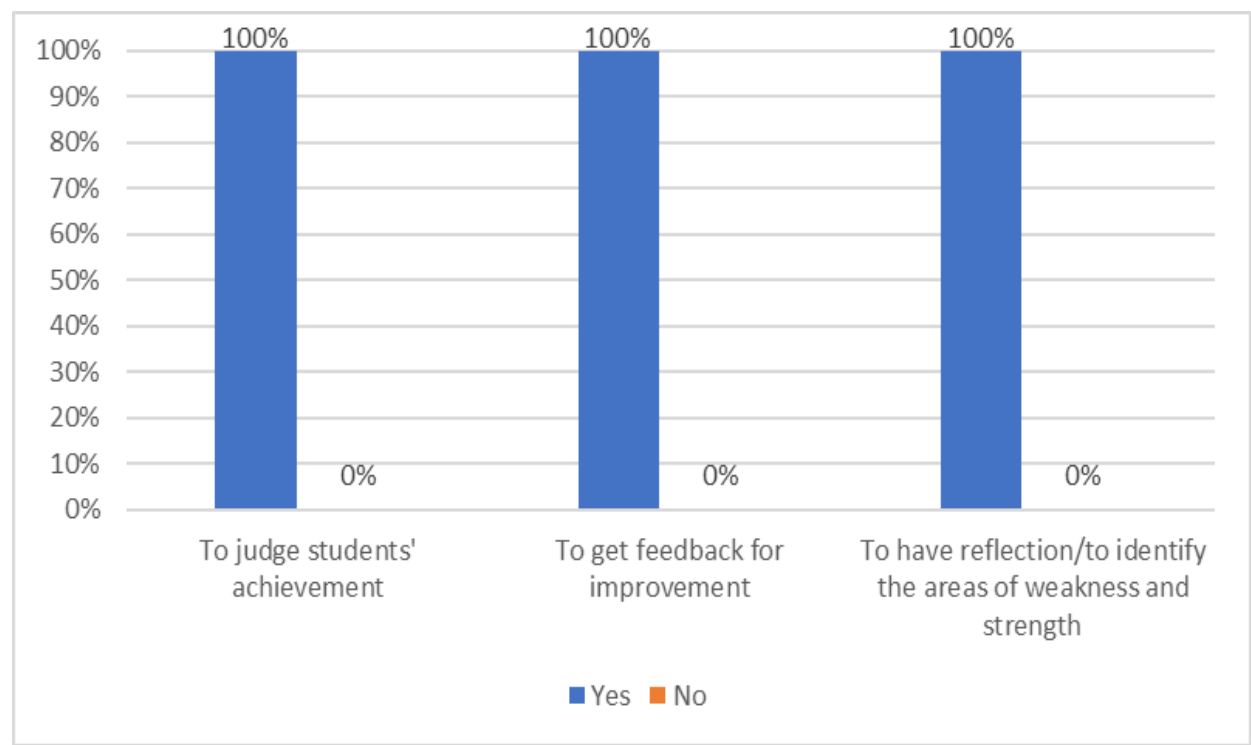

Figure 3. Aspects of Wants in the Target Need

Fig. 3 indicates the required assessments for students to be competent in using the language in use. The assessment aims to improve students' ability to use language (real-life literacy assessment), which involves the assessment to judge students' achievement, assessment instruments to get feedback for improvement, and reflections and identify the areas of weaknesses and strength. All respondents agree to these kinds of needs.

\section{B. Learners' Needs}


In addition to the target needs, the learner needs are also stated as important needs to be analyzed (Hutchinson and Waters (1987). There are several aspects of learners were analyzed: input, procedure, setting and learners' roles. Each aspect of need is summarized in the following figures.

\section{Input}

Input in this research is described as sources of materials needed for students in assessment. Based on the questionnaire and interview conducted there are several categories of input such as authentic material (integrated material), technology-based materials, skills-based material and also language based-input.

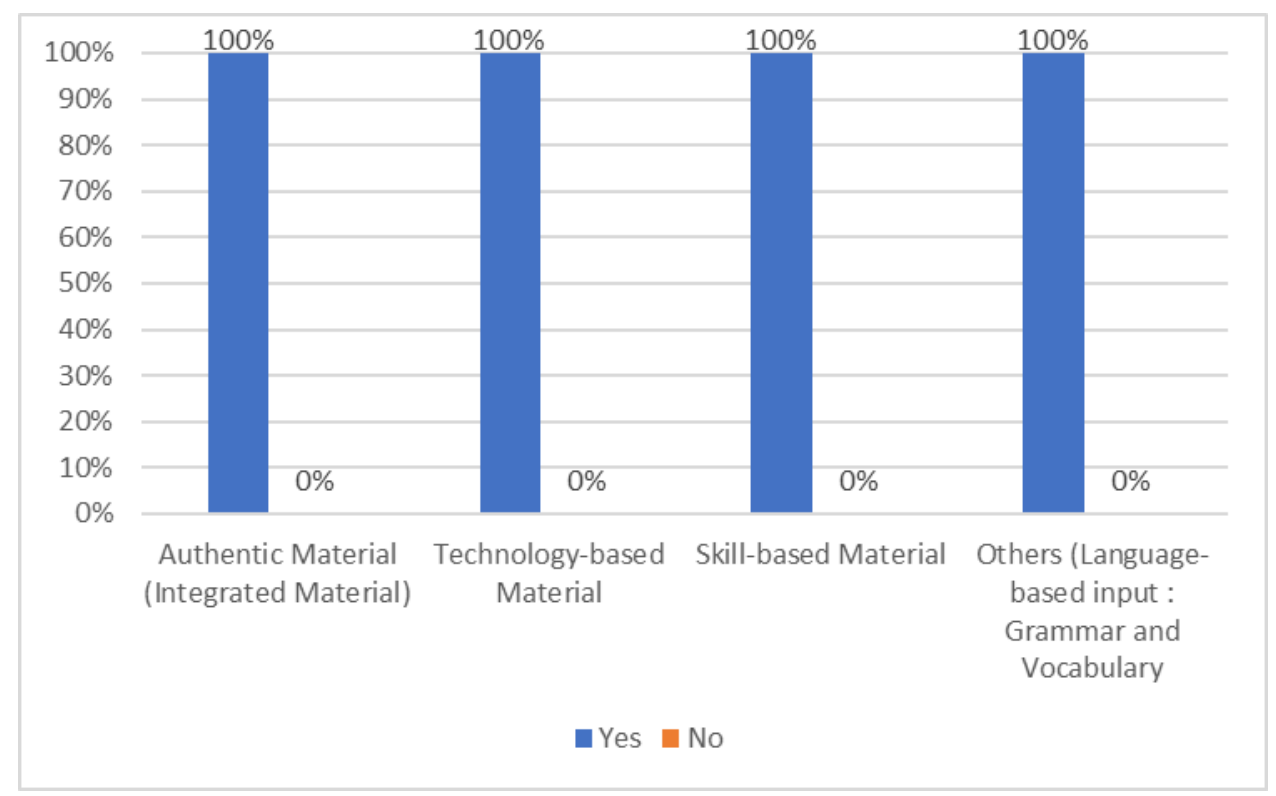

Figure 4. Aspect of Inputs in the Learners' Needs

\section{Types of Activities}

Types of activities refer to any tasks assigned to students to complete in order to meet the learner's needs. There are two types of literacy activities identified as being required such as pedagogical tasks-based literacy activities and reallife-based literacy activities.

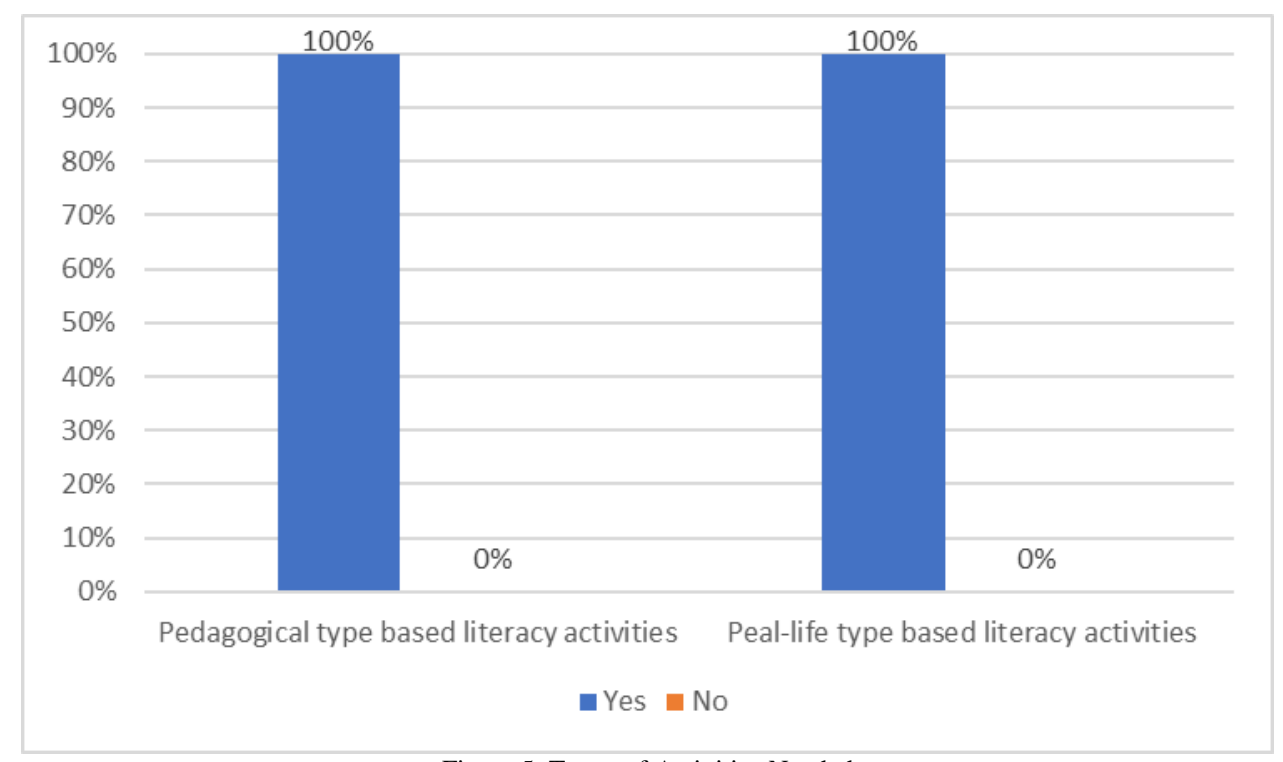

Figure 5. Types of Activities Needed

Fig. 5 reveals that all respondents agree that both kinds of activities are needed by the students. Further interviews with the respondents admitted that both kinds of activities are fundamental. The respondents further informed that assessments on the pedagogical types-based literacy activities are needed to assess the students' competency in dealing with the English literacy usage, which is a foundation for having the competency in using the language for real-life activities. 


\section{Procedure}

The procedure is another aspect of learner needs. It is concerned with the procedure of teaching in order to meet the expected learner needs of assessment. The results of the questionnaire and interviews reveal that there are two types of teaching procedures to achieve the needs of the learners in assessments, such as pedagogical-intended procedures and real-life task-based procedures, depending on the types of activities needed.

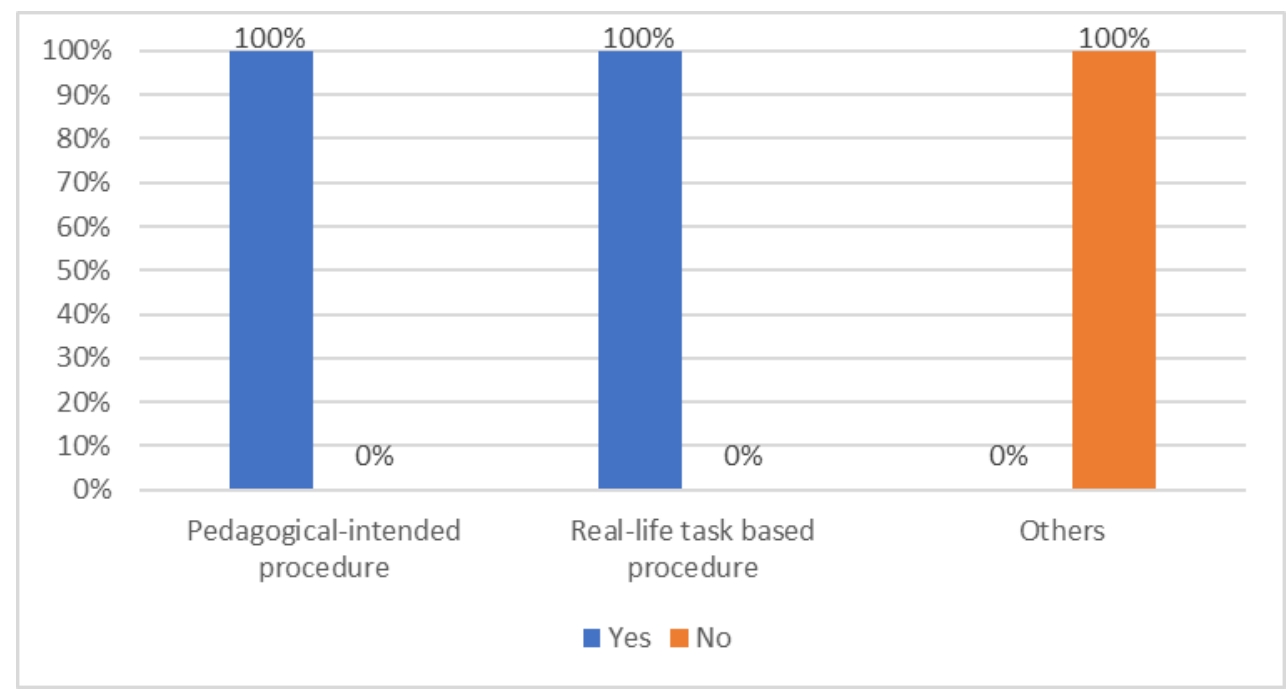

Figure 6. Procedures Needed by the Students

Fig. 6 reveals that all respondents agree that the three learning procedures are required when implementing assessments. The assessments can take the form of pedagogically intended procedures. Pedagogical intended procedures are the procedure of conducting activities that learners undertake in order to acquire language in instructional settings. On the other hand, real-life procedures are those that students perform in their daily lives while speaking the target language, in this case, English. For language learners, these also provide opportunities for language learning as well as language activation.

\section{Setting}

The setting is about when and where the assessments are conducted. Based on the results of data analysis on the questionnaire and interviews conducted, it is possible to conclude that the modes of learning used to determine the assessment settings. There are four modes of learning: synchronous mode, asynchronous mode, blended learning system, and face-to-face mode of learning.

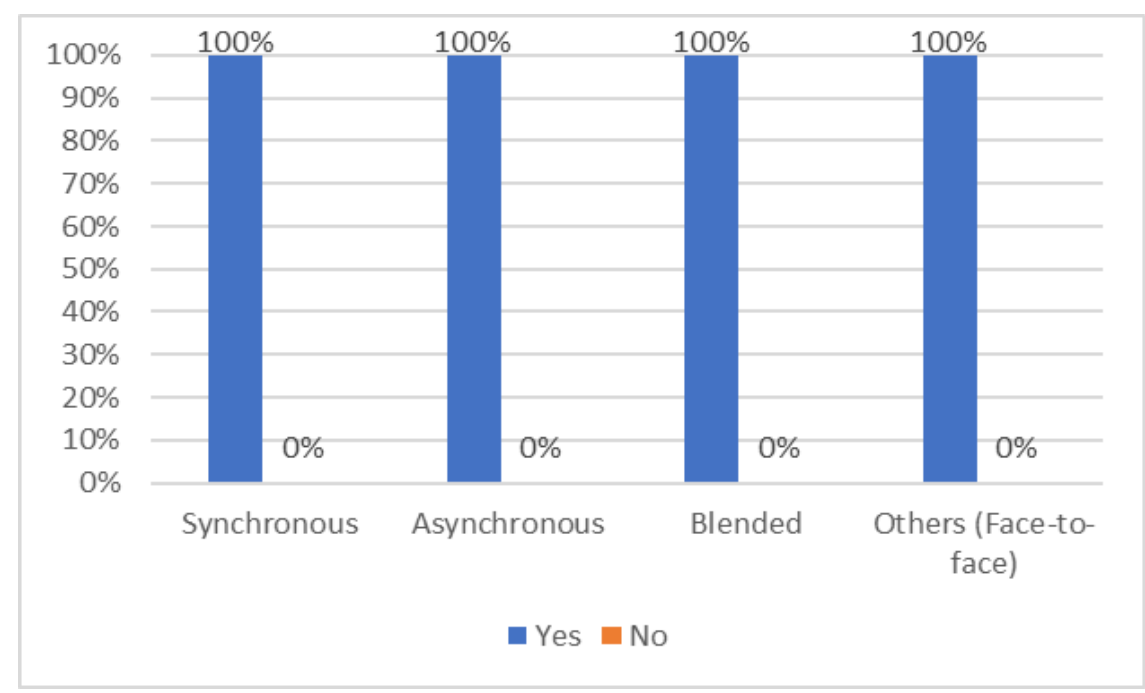

Figure 7. Types of Setting of Learning Needed by the Students

All respondents agree that all modes of learning are essential to be considered in developing the assessment instruments. The setting of the assessment is flexible and depends on the mode of learning implemented.

\section{Learner Roles}


Learner roles deal with the roles that the students must be able to perform following the completion of assessments. The results of data analysis revealed that several roles needed to be acquired by the students, such as problem solvers, communicators, knowledge seekers, and others (collaborators, critical thinkers, and creators) from which assessment instruments are developed.

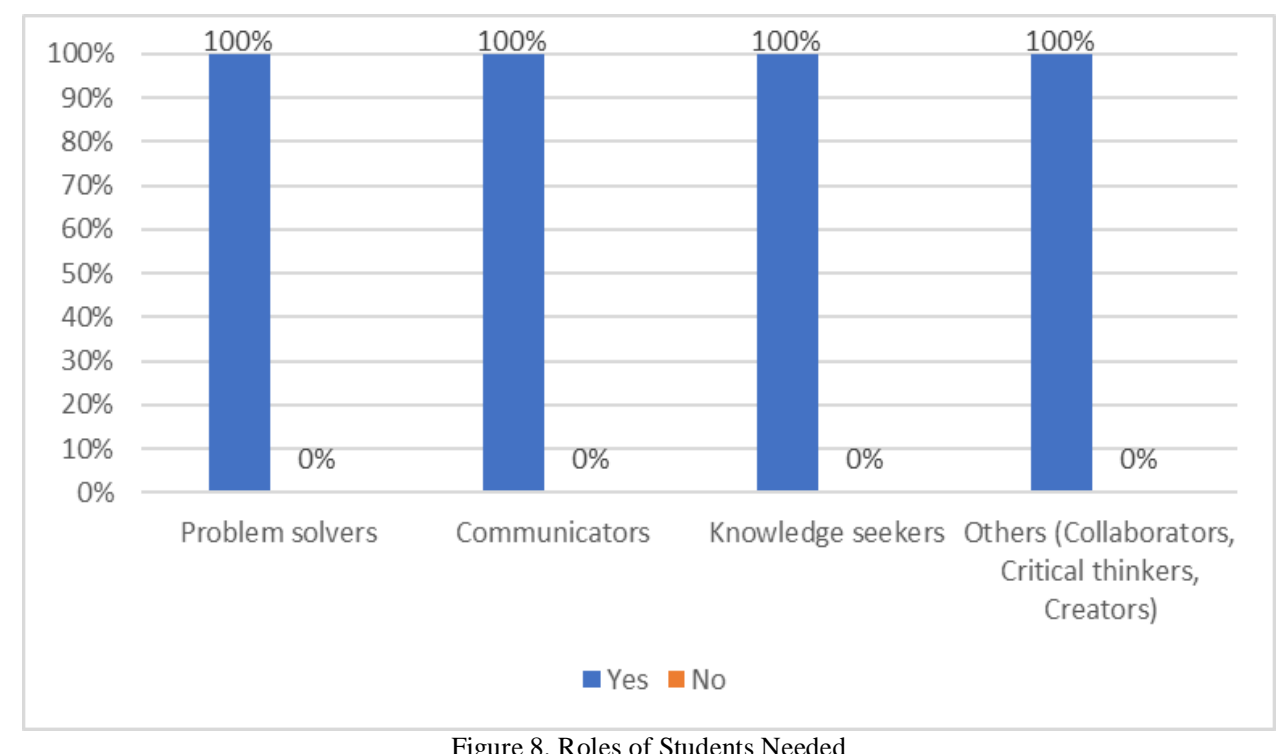

Figure 8. Roles of Students Needed

Fig. 8 demonstrates that all respondents agree on the roles of the students, which must be used as a reference for instrument assessments. With all of these needs identified, the framework for assessment needed using a blended learning system is analyzed and developed to answer the study's second research question.

\section{The Framework of Assessment Needed Using Blended Learning System}

The needs profiles were then followed up with in-depth interviews. The interviews were also continued into focused group discussions on developing the assessment framework using a blended learning system. The findings of the data collection and analysis are summarized below (see Table 1).

TABLE 1

THE FRAMEWORK OF ASSESSMENT NEEDED USING BLENDED LEARNING SYSTEM

\begin{tabular}{|c|c|c|c|}
\hline Modes of learning & Synchronous & Asynchronous & Face-to face \\
\hline Types of Assessment & $\begin{array}{l}\text { Authentic assessment: } \\
\text { Assessment as learning } \\
\text { Assessment for learning }\end{array}$ & $\begin{array}{l}\text { Authentic assessment: } \\
\text { Assessment as learning } \\
\text { Assessment for learning }\end{array}$ & $\begin{array}{l}\text { Authentic assessment: } \\
\text { Assessment of learning }\end{array}$ \\
\hline Activities & $\begin{array}{l}\text { Assessment-based } \\
\text { activities }\end{array}$ & At-home task-based assessments & Assessment based activities \\
\hline \multirow[t]{2}{*}{ Example } & $\begin{array}{l}\text { Quizzes using } \\
\text { Question/Answer session }\end{array}$ & $\begin{array}{l}\text { Formative and summative } \\
\text { assessment in the form of } \\
\text { recognition and production type of } \\
\text { assessments which are skill-based } \\
\text { and language based, both in the form } \\
\text { of pedagogical literacy based as well } \\
\text { as real-life literacy-based } \\
\text { assessments. }\end{array}$ & $\begin{array}{l}\text { Recognition and Production type } \\
\text { of assessments which are skill- } \\
\text { based and language based, both } \\
\text { in the form of pedagogical } \\
\text { literacy based as well as real-life } \\
\text { literacy-based assessments. }\end{array}$ \\
\hline & $\begin{array}{l}\text { Online quizzes (Kahoot } \\
\text { and other synchronous- } \\
\text { types of assessment). } \\
\text { Dependent and } \\
\text { independent speaking } \\
\text { assessment. }\end{array}$ & $\begin{array}{c}\text { Examples among others are: } \\
\text {-Online based assessment } \\
\text {-Writing composition } \\
\text {-Reading comprehensions } \\
\text {-Video-based } \\
\text { assessment/integrated } \\
\text { language assessment }\end{array}$ & $\begin{array}{l}\text { Examples among others are } \\
\text {-Reading comprehension } \\
\text { test } \\
\text {-Writing test } \\
\text { - Speaking dependent test } \\
\text {-Integrated listening test }\end{array}$ \\
\hline
\end{tabular}

Table 1 shows that the framework of assessment needed using the blended learning system designed has been accommodated the needs identified through the need analysis conducted. The framework recommends a blended learning system consisting of synchronous modes of learning combined with asynchronous as well as face-to-face modes of assessment. This is in line with how Alonso, López, Manrique, and Viñes (2005) defined blended learning as "learning that mixes various event-based activities: self-paced learning, live e-learning, and face-to-face classrooms". The results of interviews with the experts describe that the assessment instruments developed as real-life literacy assessments must also cover the skills of 21 st-century skills, including self-regulation, self-determination, and other learning and innovation skills. 
The current study's findings are consistent with earlier research. Due to COVID 19, Chan (2021) conducted research to include formative assessment in blended learning for Chinese language lessons. He believes that there is a need to incorporate an assessment into blended learning that would help and encourage students to self-regulate. To improve the learning experience and to attain the desired outcome of blended learning, formative assessment (FA) is recommended. He discovered that FA encourages students to set learning goals, self-evaluate, reflect, change, and improve their learning through online or face-to-face meetings. He went on to say that the most crucial aspect of FA was feedback. Teachers must choose which modes (online or conventional) will be more beneficial in improving the language skills of their students.

The respondents reconfirmed that all modes of learning and assessment designed as shown in the framework are considered to be important and useful, because the framework is perceived as beneficial not only during online learning but also as an essential framework even in the process of learning post-pandemic or in the new normal situation. The types of assessments recommended consist of three approaches, which are assessment of learning, assessment for learning, and assessment as learning. It is critical and highly essential to incorporate multiple assessment methods into the process of developing English literacy. The more information gathered and used to make decisions about the students' assessments, strengths, and weaknesses, the better the decision will be. Assessment is the process of collecting information on student learning outcomes from measurements in order to explain or analyze student performance on assignments and tests assigned by the teacher (Wulan, 2007).

The findings of this investigation are also coherent with those of Titov, Kurilov, Titova, and Brikoshina (2019). They researched university students that combined summative and formative evaluation in blended learning. Summative evaluation refers to the final grade and is more formal and traditional than formative assessment. Summative assessment alone is insufficient for thoroughly assessing students' learning. To address the limitations of summative evaluation in blended learning, formative assessment, which monitors students' learning progress, is used. The teacher or practitioners in blended learning might use integrative assessment to examine the interaction between computer-assisted and traditional activities and their impact on the learning experience.

The framework's emphasis on implementing authentic assessment supports the study by Zaim, Refnaldi, and Arsyad (2020). They conducted a research and development study on authentic assessment to evaluate the English language skills of Junior High School students. The assessment was developed to determine the teacher's needs for speaking skills assessment and develop an authentic assessment model that is appropriate for the needs of both teachers and students. This study used the ADDIE model, in which data was collected from a questionnaire distributed to teachers. According to the findings of the study, the appropriate needs analysis could be used effectively for assessing students' speaking abilities. Although this study has limitations because it only uses self-perceptions for teachers, this research is useful for teachers to provide accurate assessments. In addition, through this assessment, students can realize their abilities and find out what skills they need to improve.

Despite the framework resulting from this research, the present study does not cover the development of the framework into completed and finished assessment instruments ready for use because the instruments can be further developed based on the existing situation of the schools. In other words, any teacher or lecturer can further develop the framework into instruments based on the context of the situation in the schools. With the needs profile identified and the framework developed, the present study is expected to inspire all teachers worldwide who teach English literacy as a foreign language in junior high schools to develop assessments based on these findings.

\section{CONCLUSION}

Understanding the needs of assessment instruments is crucially important in developing English literacy skills. The data on needs can be treated as the basis for the development of literacy assessment instruments for blended learning. Identifying target needs and learner needs can guide teachers to develop quality instructions, learning outcomes, and help students achieve literacy skills in English as a Foreign Language. Furthermore, incorporating technology into the assessments design and implementation is an effort to incorporate $21^{\text {st }}$ century skills through English lesson. This study identified the needs for assessment instruments and developed the assessment framework for blended learning. The framework may be used as a guide for assessment instruments by researchers who can benefit from it in the future.

\section{REFERENCES}

[1] Akyel, A. S., \& Ozek, Y. (2010). A Language needs analysis research at an English medium university in Turkey. Procedia Social and Behavioral Sciences, 2(2), 969-975. https://doi.org/10.1016/j.sbspro.2010.03.136.

[2] Aliningsih, F., \& Sofwan, A. (2015). English teachers' perception and practices of authentic assessment. Language Circle: Journal of Language and Literature, 9(1), 19-27.

[3] Alonso, F., López, G., Manrique, D., \& Viñes, J. M. (2005). An instructional model for web-based e-learning education. British Journal of Educational Technology, 36(2), 217-235.

[4] Anugerahwati, M. (2019). Integrating the 6Cs of 21st-century education into the English lesson in the school literacy movement in secondary school. International Seminar on Language, Education, and Culture (pp. 165 - 171). KnE Social Sciences. 
[5] Apsari, Y., \& Haryudin, A. (2017). The analysis of English lecturers' classroom-based reading assessments to improve students' reading comprehension. ELTIN: Journal of English Language Teaching in Indonesia, 5(1), 35-44.

[6] Aziz, M. N., \& Yusoff, N. M. (2016). Improving process writing with the use of authentic assessment. International Journal of Evaluation and Research in Education, 5(3), 200-204.

[7] Aziz, M. N., Yusoff, N. M., \& Yaakob, M. F. (2020). Challenges in using authentic assessment in 21st century ESL classrooms. International Journal of Evaluation and Research in Education, 9(3), 759-768.

[8] Chan, K. T. (2021). Embedding formative assessment in blended learning environment: The case of secondary Chinese language teaching in Singapore. Education Sciences, 11(7), 360. https://doi.org/10.3390/educsci11070360

[9] Cheung, W. S., \& Hew, K. F. (2011). Design and evaluation of two blended learning approaches Lessons learned. Australasian Journal of Educational Technology, 27(8), 1319-1337

[10] Creswell, J. W. (2009). Research Design Qualitative, Quantitative, and Mixed Methods Approaches. Sage Publications Inc.

[11] Damaianti, V. S., Abidin, Y., \& Rahma, R. (2020). Higher-order thinking skills-based reading literacy assessment instrument: an Indonesian context. Indonesian Journal of Applied Linguistics, 10(2), 513-525.

[12] Eridafithri. (2015). The application of portfolios to assess progress in writing of EFL students at secondary schools in banda Aceh. Studies in English Language and Education, 2(1), 1-15.

[13] Eslami, Z. R. (2010). Teachers' voice vs. students' voice: A needs analysis approach. English Language Teaching, 3(1), 1-11.

[14] Fahmi, Pratolo, B. W., \& Zahruni, N. A. (2020). Dynamic assessment effect on speaking performance of Indonesian EFL learners. International Journal of Evaluation and Research in Education, 9(3), 778-790.

[15] Fullan, M., \& Duckworth, S. (2015). $21^{\text {st }}$ Century Skills: 6 Cs of Education. (www.blogwwap.com) retrieved on July 15, 2018

[16] Gupta, K., Sleezer, C. M., \& Russ-Eft, D. F. (2007). A Practical Guide to Needs Assessment (Vol. 2). Pfeiffer.

[17] Hutchinson, T., \& Waters, A. (1987). English for Specific Purposes: A Learner-Centered Approach. Cambridge University Press.

[18] Inayah, N., Komariah, E., \& Nasir, A. (2019). The practice of authentic assessment in an EFL classroom. Studies in English Language and Education, 6(1), 152-162.

[19] Isti'anah, A. (2017). The effect of blended learning to the student's achievement in grammar class. Indonesian Journal of English Education, 4(1), 16-30.

[20] Li, J., Kay, R., \& Markovich, L. (2018). Student attitudes toward blended learning in adult literacy and basic skills college programs. Canadian Journal of Learning and Technology, 44(2), 1-36.

[21] Littlejohn, A., \& Pegler, C. (2007). Preparing for blended e-learning. Routledge.

[22] McKay, P. (2006). Assessing young language learners. Cambridge University Press.

[23] Miller, B.S. (2015). The 6Cs Squared Version of Education in the $21^{\text {st }}$ Century (www.bamradionetwork.com) retrieved on July 26, 2018

[24] Nodoushan, M. A. (2014). Assessing writing: A review of the main trends. Studies in English Language and Education, 1(2), 116-125.

[25] Nunan, D. (2004). Task-based language teaching. Cambridge University Press.

[26] Nuryana, Z., Suroyo, A., Nurcahyati, I., Setiawan, F., \& Rahman, A. (2020). Literation movement for leading schools: Best practice and leadership power. International Journal of Evaluation and Research in Education, 9(1), 227-233.

[27] Padmadewi, N. N., \& Artini, L. P. (2017). Literasi di Sekolah. Dari Teori ke Praktik. Nilacakra.

[28] Priyatni, E. T., \& Martutik. (2018). Developing assessment as learning based on problem-solving to promote university students' Skills in critical-creative thinking. SLLAC: Journal of Intensive Studies on Language, Literature, Art, and Culture, 2(2), 56-69.

[29] Purcell-Gates, V., Anderson, J., Gagne, M., Jang, K., Lenters, K. A., \& McTavish, M. (2012). Measuring situated literacy activity: Challenges and promises. Journal of Literacy Research, 44(4), 396-425.

[30] Rahmawanti, M. R., \& Uman, A. (2019). Integrating web 2.0 tools in writing class to promote assessment for learning. Journal of English Educators Society, 4(2), 53-59.

[31] Ramadhan, R., Chaeruman, U. A., \& Kustandi, C. (2018). Pengembangan pembelajaran bauran (Blended Learning) di Universitas Negeri Jakarta. Jurnal Pembelajaran Inovatif, 1(1), 37-48.

[32] Rintaningrum, R. (2009). Literacy: Its importance and changes in the concept and definition. TEFLIN Journal, 20(1), 1-7.

[33] Shohamy, E. (2001). The Power of Tests: A Critical Perspective on the Use of Language Texts. Journal of Writing Assessment, 3(1), 55-60.

[34] Stiggins, R. (2005). From formative assessment to assessment for learning: A Path to success in standards-based schools. Phi Delta Kappan, 87(4), 324-328.

[35] Suastra, I. M., \& Menggo, S. (2020). Empowering students' writing skills through performance assessment. International Journal of Language Education, 4(3), 432-441.

[36] Sumardi, S., \& Muamaroh, M. (2020). Edmodo impacts: Mediating digital class and assessment in English language teaching. Cakrawala Pendidikan, 39(2), 319-331.

[37] Titov, S., Kurilov, A., Titova, N., \& Brikoshina, I. (2019). Integrative Assessment Framework in Blended Learning. TEM Journal, 8(3), 768-774.

[38] Wulan, A. R. (2007). Pengertian dan esensi konsep evaluasi, asesmen, tes, dan pengukuran. Retrieved May 15, 2021, from http://file. upi.edu/direktori/fpmipa/jurpend_bio logi/ana ratnawulan/pengertianasesmen.pdf.

[39] Yulia, A., Husin, N. A., \& Anuar, F. I. (2019). Channeling assessments in English language learning via interactive online platforms. Studies in English Language and Education, 6(2), 228-238.

[40] Zaim, M., Refnaldi, \& Arsyad, S. (2020). Authentic assessment for speaking skills: problem and solution for English secondary school teachers in Indonesia. International Journal of Instruction, 13(3), 587-604. 


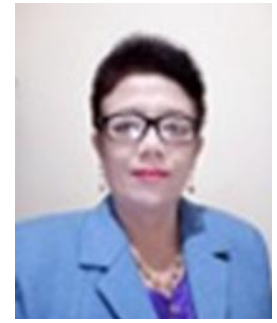

Ni Nyoman Padmadewi was born in Tabanan, Bali, Indonesia in 1962. She finished her undergraduate degree in English Education at Udayana University, Denpasar, Bali, Indonesia in 1986. A Master's degree in Education was obtained from the School of Education at Macquarie University, NSW, Australia in 1993, and a Doctorate degree in Linguistics was completed at Udayana University, Denpasar, Bali, Indonesia in 2005. She is a professor in English language Education and is currently the Coordinator of the Master's Degree Program in English Language Education, Universitas Pendidikan Ganesha, Bali, Indonesia. She is an educator, researcher and book authors, and external examiners for $\mathrm{PhD}$ dissertation in several universities in Indonesia and overseas. Some of her works are 1) Padmadewi, N.N. and Artini, L.P. (2019). Assessment instruments for improving English teaching skills through microteaching in Indonesia, Asian EFL Journal, 21(2), 49-77; 2) Padmadewi, N.N., and L.P. Artini (2017). Teaching English in an Indonesian Regular Classroom to a Student with Autism Spectrum Disorder. International Journal of Instruction, 10(3), 159-176, and 3) Padmadewi, N.N. (2016). Techniques for promoting autonomous learning in the classroom. Journal of Education and Social Sciences, Vol. 3, (Feb.), 45-52. Her research interests are in literacy and English language teaching, English teaching methods, teaching English to young learners, designing curriculum, teaching English to students with special needs, and innovations in English language teaching. Prof. Padmadewi is a member of several professional organizations, including Teaching English as a Foreign Language Indonesia (TEFLIN Indonesia) and a life-time membership of ASIA TEFL. Prof. Padmadewi is also the founder of a bilingual kindergarten and primary school in North Bali, Indonesia, as well as a consultant for curriculum designs in teaching English for students with special needs in North Bali Indoensia, and a reviewer for many international journals.

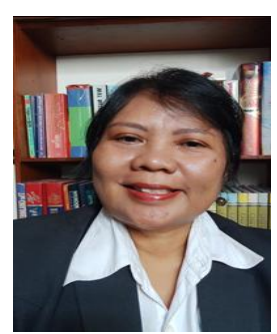

Luh Putu Artini is a professor in English language education and currently teaches at the English Language Education, post Graduate Study Program, Universitas Pendidikan Ganesha, Bali, Indonesia. She earned her bachelor degree from Udayana University, Bali (1987); master degree from La Trobe University, Australia (1994), and Ph.D. in Education from Newcastle University, Australia (2006). She attended a non-degree training on Bilingual Education in Leuven Education College, Belgium (2009); and Early Literacy in Indiana University (2010). Artini is an educator, researcher and invited speaker in many teachers' forums and conferences. She is also an external examiner for $\mathrm{PhD}$ dissertations in some universities, and a reviewer of many international journals. Some of her works are: Rich Language Learning Environment and Young Learners' Literacy Skills in English (Lingua Cultura, 2017), Project Based Learning in EFL Classes: Material Development and Impact of Implementation (Dutch Journal of Applied Linguistics, 2018); Assessment Instruments for improving English Teaching Skills through Micro Teaching in Indonesia (Asian EFL Journal, 2019); Does Problem Based Learning affect students' speaking skills and attitudes toward ELL? (Retorika, 2020); Self-Directed Learning during Pandemic: An Analysis of students' perceptions and Learning autonomy (Language and Education Journal, 2021). She authored 10 books in the area of English Language Teaching. Her research interests include EFL Pedagogy, Bilingual Education, Teaching English for Young Learners, and Early Literacy. Artini is the member of three international professional organizations: Teaching English as a Foreign Language in Indonesia (TEFLIN), ASIA TEFL, and International Society for Development \& Sustainability.

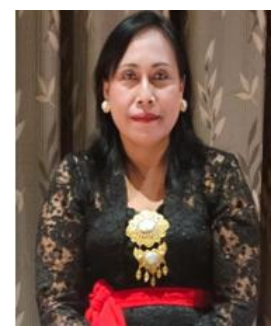

Ni Made Ratminingsih and was born in Singaraja, Bali, Indonesia in 1966. Ratminingsih accomplished her undergraduate degree in English Education at Udayana University, Denpasar, Bali, Indonesia in 1990. She yielded a Master's degree from Deakin University, Australia in 1997 and Doctorate degree from Jakarta State University in 2011. She has been an academic staff of English Study Program of Foreign Languages Department since 1991 and English Study Program at Post Graduate Program of Universitas Pendidikan Ganesha (abbbreviated Undiksha) Singaraja-Bali since 2011. She has also published books in nationally known publishers and articles in reputable international and national journals, namely (1) Ratminingsih, N.M. (2017). Metode dan Strategi Pembelajaran Bahasa Inggris. Depok: Rajagrafindo Persada. (2) Ratminingsih, N.M., Marhaeni, A.A.I.N., \& Vigayanti, L.P.D. (2018). Self-Assessment: The Effect on Students' Independence and Writing Competence. Instructional Journal of Instruction, 11(3), 277-290, and (3) Ratminingsih, N.M, Artini, L.P., \& Padmadewi, N.N. (2017). Incorporating Self and Peer Assessment in Reflective Teaching Practices. Instructional Journal of Instruction, 10(4), 165-184. Her research interests are TEYL and TEFL particularly in the development and implementation of innovative teaching strategy, media, assessment, and literacy. She won many multi-year research grants from the Directorate General of Research and Development Strengthening, Ministry of Research, Technology and Higher Education several times. Some of the research are: The Development of Games in Learning English in Elementary Schools (2015-2016), Development of Local CultureBased Picture Storybooks for Learning English in Elementary Schools (2017-2019), and Application of Technology Integrated Multi Language Literacy through Print and Digital Dictionaries in Elementary Schools in Buleleng Regency (2021-2022). Prof. Ratminingsih is a member of two professional organizations in English Education in Asia, Teaching English as a Foreign Language Indonesia (TEFLIN Indonesia) and a life-time membership of ASIA TEFL

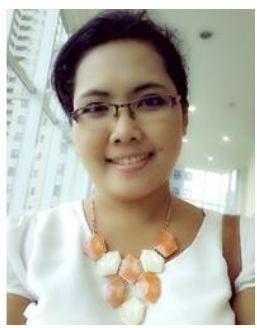

IGA Lokita P. Utami was born in Singaraja, 2 April 1983. She studied at English Language Education of IKIP N singaraja and earned her bachelor degree in 2005. She enrolled a master degree program of Language Education of universitas Pendidikan Ganesha in 2008 and graduated in 2010. In 2018, she earned her doctoral degree of English Language education from Universitas Negeri Malang, in Malang, Indonesia.

She is currently a lecturer at English Language education department of Universitas Pendidikan Ganesha, Singaraja, Indonesia. Her research interests are on teacher professional development, English language instruction, the use of technology in language teaching as well as literature teaching. She has authored also coauthored papers and book chapters in national and international journals and publications. She has begun 
international writing collaborations with world researchers from Australia, the United States, and Belgium since 2018. These collaborations have resulted in international publications as follows: Prestridge, S., Utami, IGA Lokita P Utami, Mein, K. 2021. A cross-cultural comparison: the socio-technical affordances of social media as a professional learning tool for teachers. Teacher Development. https://doi.org/10.1080/13664530.2021.1895881 Utami, IGA Lokita P Utami, Prestridge, S., Saukah,A., Fuad, A.H. 2019. Continuing Professional Development and teachers' perceptions and practices - A tenable relationship. International journal of Applied Linguistics,9(1), May 2019Pp 108-118. http://ejournal.upi.edu/index.php/IJAL/article/download/12463/9688 Utami, IGA Lokita P Utami, Prestridge, S. (2018). How English Teachers Learn in Indonesia: Tension Between Policy-Driven And Self-Driven Professional Development. TEFLIN journal, 29( 2): 245-265. http://journal.teflin.org/index.php/journal/article/view/591/302

Dr. Utami's joined association of English Education department in Indonesia and TEFLIN (Teaching English as a Foreign Language in Indonesia) Association. In 2008, her research team received a research grant from the World Bank through the IMHERE projects. The study was designed to look into students' pragmatic competence. She has also received various institution-based research grants (2008-present) in the field of English education and literature education. In 2013, she was awarded a prestigious national research grant from the Ministry of Research and Technology to develop a literature-based teaching model. Throughout her doctoral studies, she actively published journals and book chapters. In 2017, she was awarded a scholarship from The Ministry of research and technology for an international publication mentorship program, which allowed her to study for a short period of time at Griffith University in Australia. In 2017, a reputable international journal (Q2), ASIA TEFL journal, published her journal article on Continuous Professional Development. This journal publication also received a national award by the ministry of research and technology in the category of a beginner writer. List any memberships in professional societies like the IEEE. Finally, list any awards and work for professional committees and publications. Personal hobbies should not be included in the biography.

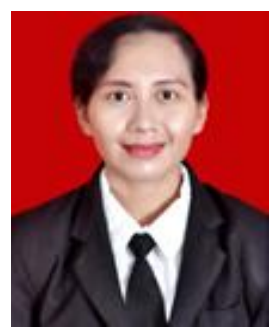

Ni Putu Era Marsakawati was born in Manggis, 14 March 1983. She finished her undergraduate study in 2006 at Universitas Pendidikan Ganesha. In 2008, she continued her study in this university and received her master degree in English education in 2010. In 2015, she pursued her doctoral degree in Universitas Negeri Semarang, Indonesia and earned her doctoral degree on English Education in 2019.

She is a teaching staff member of Foreign Language Department of Universitas Pendidikan Ganesha. She has been teaching courses related to English Education, such as Strategies and Design of Teaching and Teaching for ESP. Her passion on teaching has motivated her to conduct research and community services in the area of English language teaching. She has been facilitating novice teachers to develop their teaching skills. She has been writing articles in reputable journals. In 2019, one of her research article was published in ASIA TEFL Journal. She is a member of TEFLIN (Teaching English as a Foreign Language in Indonesia) association and loves to collaborate with experts, particularly in English language teaching. 